\title{
NHERF1/EBP50 in Breast Cancer: Clinical Perspectives
}

\author{
Antonia Bellizzi $^{\mathrm{a}^{*}}$ Andrea Malfettone $\mathrm{a}^{\mathrm{a}^{*}}$ Rosa A. Cardone ${ }^{\mathrm{b}} \quad$ Anita Mangia $^{\mathrm{a}}$ \\ ${ }^{a}$ Clinical Experimental Oncology Laboratory, National Cancer Centre, Bari, \\ ${ }^{\mathrm{b}}$ Department of General and Environmental Physiology, University of Bari, Italy \\ * Both authors equally contributed to this work.
}

\section{Key Words}

Breast cancer $\times$ NHERF1/EBP50 $\times$ HER2/neu

\section{Summary}

$\mathrm{Na}^{+} / \mathrm{H}^{+}$exchanger regulatory factor 1 (NHERF1) is a postsynaptic density 95/disc-large/zona occludens (PDZ) domain-containing protein that recruits membrane receptors/transporters and cytoplasmic signaling proteins into functional complexes. NHERF1 expression has been demonstrated to be altered in breast cancer, but its role in mammary cancerogenesis and progression remains still undefined. In this paper, we review what is known on the pathological role and the potential clinical application of NHERF1 protein in breast cancer. Recent evidence shows that an increased cytoplasmic expression of NHERF1 suggests a key role of its localization/compartmentalization in defining cancerogenesis, progression, and invasion. NHERF1 overexpression is associated with increasing tumor cytohistological grade, aggressive clinical behavior, unfavorable prognosis, and increased tumor hypoxia. Moreover, NHERF1 co-localizes with the oncogenic receptor HER2/neu in HER2/neu-overexpressing carcinoma and in distant metastases. These data make NHERF1 also a potential candidate of clinical relevance for anti-HER2/neu therapy.

\section{Introduction}

Breast cancer is still a major cause of death in women. In fact, although the increasing body of knowledge in the field of molecular biology has allowed for a better understanding

\author{
Schlüsselwörter \\ Mammakarzinom $\times$ NHERF1/EBP50 × HER2/neu
}

\section{Zusammenfassung}

Das NHERF1 $\left(\mathrm{Na}^{+} / \mathrm{H}^{+}\right.$exchanger regulatory factor 1$)$-Protein besitzt eine PDZ (postsynaptic density 95/disc-large/ zona occludens)-Domäne und schließt Membranrezeptoren/Transporter und zytoplasmatische Signalproteine zu funktionellen Komplexen zusammen. Es ist gezeigt worden, dass bei Mammakarzinomen eine veränderte NHERF1-Expression vorliegt. Die Rolle des Proteins bei der Karzinogenese und Progression von Mammakarzinomen ist jedoch noch unklar. Im vorliegenden Artikel geben wir einen Überblick über das Wissen bezüglich der pathologischen Rolle und potentiellen klinischen Anwendung des NHERF1-Proteins beim Mammakarzinom. Neuesten Erkenntnissen zufolge deutet die erhöhte zytoplasmatische Expression von NHERF1 auf eine Schlüsselrolle seiner Lokalisation/Kompartimentierung bei der Festlegung der Karzinogenese, Progression und Invasion hin. NHERF1-Überexpression ist mit erhöhtem zytohistologischen Grad, aggressivem klinischen Verhalten, ungünstiger Prognose und verstärkter Tumorhypoxie assoziiert. Außerdem liegt eine Kolokalisation von NHERF1 mit dem onkogenen Rezeptor HER2/neu in HER2/neu-überexpremierenden Karzinomen und in Fernmetastasen vor. Diesen Daten zufolge ist NHERF1 ein klinisch relevanter, potentieller Kandidat für die Anti-HER2/neu-Therapie.

of the biology of breast cancer, the search is still in progress for new factors that would make it possible to personalize therapeutic approaches and optimize the employment of targeted therapies. Today, several biological characteristics such as estrogen receptor (ER), progesterone receptor (PR),

\begin{tabular}{ll}
\hline KARGER & ( ) 2010 S. Karger GmbH, Freiburg \\
Fax +497614520714 & Accessible online at: \\
Information@Karger.de & www.karger.com/brc \\
www.karger.com &
\end{tabular}


proliferation markers, and HER2/neu expression are considered useful biomarkers for a better selection of candidates for various therapeutic approaches [1], but their clinical utilization is often not easy because of contradictory characteristics when determined in the single patient and suboptimal performance.

The biomolecular complexity and pathological heterogeneity of breast cancer are the reasons for the varied clinical outcome and response to therapy of breast cancer patients, stressing the need for further studies on molecular pathways involved in cell signaling, controlling cell growth, death, and tumor differentiation. Signaling pathways are organized into macromolecular assemblies by scaffolding proteins containing PDZ modular interaction domains that facilitate the association of multiple target proteins and permit the creation of new tumor-specific pathways to drive the subverted cellular functions exhibited by tumor cells. One class of modular domains is the postsynaptic density 95/disc-large/zona occludens (PDZ) domain that associates with specific carboxyl-terminal motifs on target proteins and can also oligomerize with other PDZ domains to enhance the scaffolding function [2, 3]. In particular, human $\mathrm{Na}^{+} / \mathrm{H}^{+}$exchanger regulatory factor 1 (NHERF1), initially identified as ezrin-radixin-moesin (ERM)binding phosphoprotein 50 (EBP50), is a protein comprising 358 amino acids and containing 2 tandem PDZ domains followed by a carboxyterminal ERM-binding region that recruits membrane receptors/transporters and cytoplasmic signaling proteins into functional complexes important for the coordination of multiple signaling pathways such as those depending on tyrosine kinase (TK) receptors [4].

Different methodologies for the analysis of NHERF1 characteristics in human tissues have been applied, either by combining immunohistochemistry and in situ hybridization [5], or immunofluorescence with Western blot (WB) analysis of the tumor samples [6]. These studies showed a wide distribution of NHERF1 in normal human tissues, and in particular those containing polarized epithelia [7-9]. Here, we review the available data on the role of NHERF1 in the pathogenesis and progression of breast cancer, stressing those aspects of potential clinical application.

\section{NHERF1 in Breast Cancerogenesis and Progression}

NHERF1 is a candidate tumor suppressor gene located at chromosome loci 17q25.1 [7, 10, 11]. Loss of heterozygosity (LOH) at the NHERF1 gene locus (SLC9A3R1) occurs frequently in human ovarian cancer and breast cancer, in the latter in more than $50 \%$ of tumors [12-14]. Conversely, LOH at the NHERF1 locus is not frequent in other types of human cancer, supporting the hypothesis that NHERF1 is specifically targeted during breast tumorigenesis [11]. Protein expression has been reported to be altered in several cancers such as hepatocellular carcinomas [15] and in

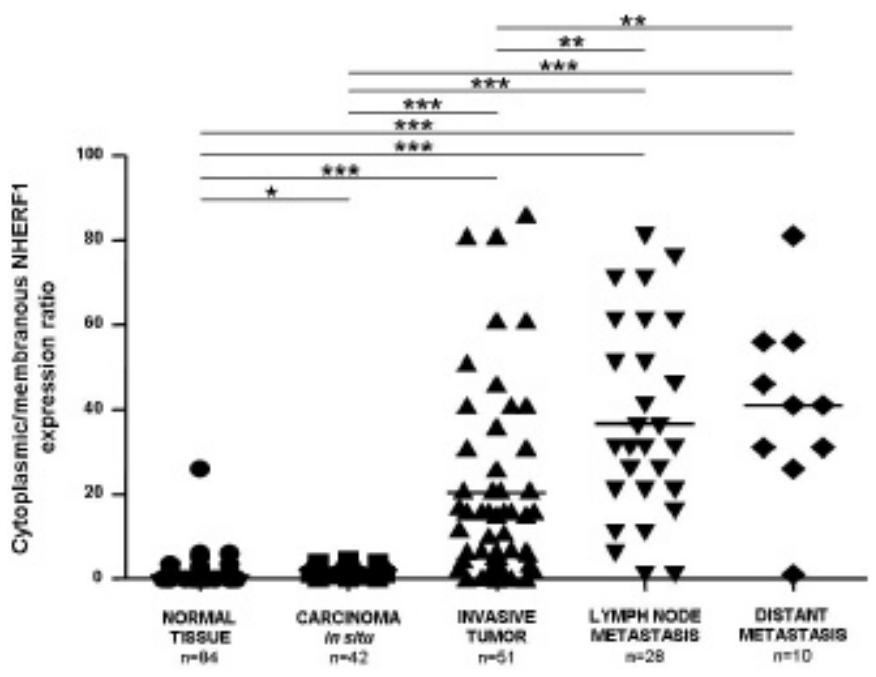

Fig. 1. Cellular distribution of NHERF1 in breast tissues. Cytoplasmic/ membranous NHERF1 protein expression ratio evaluated in normal breast tissue, carcinoma in situ, invasive tumor, synchronous metastatic lymph nodes, and metachronous distant metastasis tissues (horizontal bold line in the box marks mean value; ***p $<0.0001$, ** $\mathrm{p}<0.001, * \mathrm{p}<0.01$, by parametric unpaired t-test).

schwannoma [16]; however, the most representative data concerns altered expression in breast cancer samples [17] in which significant relationships with clinical pathological characteristics of the tumor have been also reported [5, 6, 18]. By analyzing NHERF1 protein expression in human breast tumors and contiguous noninvolved tissue from the same patient, Cardone et al. [6] demonstrated that NHERF1 is overexpressed in all human breast tumors with respect to contiguous normal lobules. Even more interestingly, Mangia et al. [19] described a significant change in subcellular distribution of NHERF1 moving from less to more aggressive breast cancers. Interestingly, in tumor cells from either primary or metastatic sites, NHERF1 protein was mostly localized in the cytoplasm of epithelial cells while membranous NHERF1 immunoreactivity was present especially at the luminal aspects of normal breast epithelial cells [8]. Furthermore, the cytoplasmic/membranous NHERF1 expression ratio (fig. 1) progressively increased in tumors cells from ductal carcinoma in situ (DCIS) to primary invasive and metastatic tissues. The altered subcellular compartmentalization of NHERF1 in DCIS seems to suggest that it could play an early pathogenetic role in breast cancer progression (fig. 2). Based on these findings, Georgescu et al. [20] hypothesized that NHERF1 could act as a tumor suppressor when localized at the apical level of the membrane, and as an oncogenic protein when localized in the cytoplasm. Indeed, in comedocarcinomas, subluminal membranous immunoreactivity of NHERF1 was present. Comedo-type DCIS is a breast cancer characterized by an important central necrosis [21] caused by marked tumor cells proliferation and hy- 
Fig. 2. Immunohistochemical analysis of NHERF1 protein in breast cancer. NHERF1 expression in $\mathbf{A}$ morphologically normal tissue is present as apical membranous reactivity; B in carcinoma in situ NHERF1 immunoreactivity is localized in the cytoplasmic subcellular compartment and in the membrane of subluminal cells;

C in invasive tumor NHERF1 is present as cytoplasmic staining (original magnification $\times 400$ ).
A
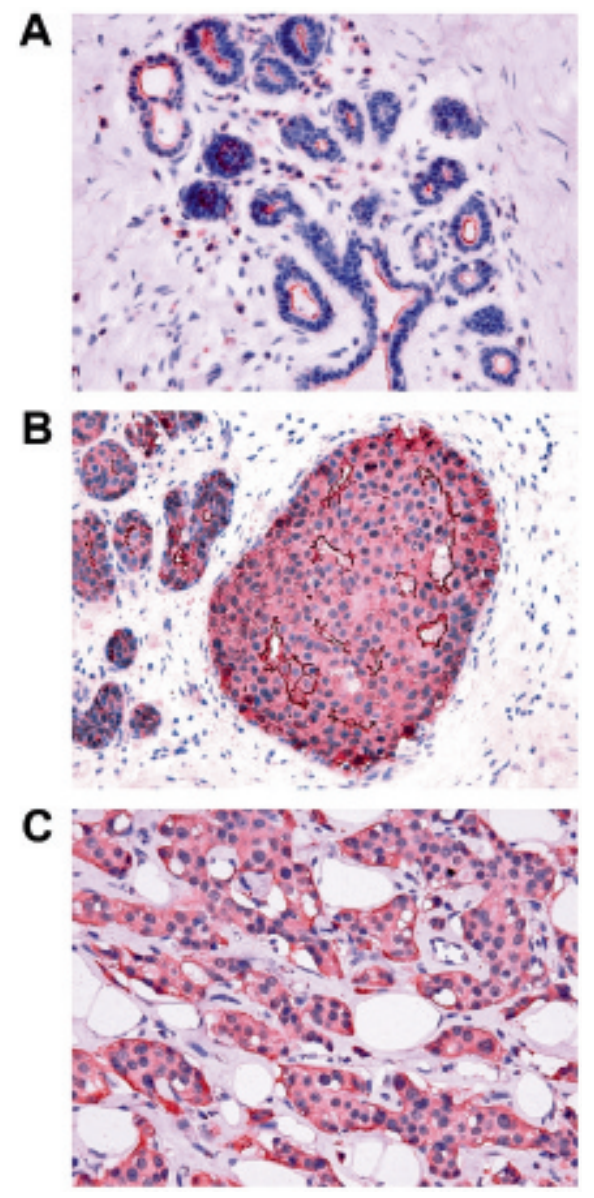

\section{NHERF1 Correlation with Clinicopathological Characteristics}

NHERF1 protein expression was analyzed with respect to the main clinicopathological characteristics of women with breast cancer (table 1), such as age, menopausal status, tumor size, proliferation index (MIB1), presence of regional nodal metastases (node status), ER and PR status, and tumor cytohistological differentiation grade $[5,6,18]$.

In relation to hormone receptors, it is noteworthy that NHERF1 expression is present in $90-93 \%$ of ER-positive breast tumors while being completely absent in the $62-71 \%$ of ER-negative tumors [5, 8]. In any case, tumor NHERF1 protein expression levels were reported as directly related with increasing ER levels in ER-positive tumors. This evidence biologically interprets the results of experiments describing the NHERF1 gene as transcriptionally regulated by estrogen [28, 29]. Moreover, NHERF1 expression signifi-

Table 1. Clinicopathological association of NHERF1 protein expression levels in human breast tumor tissues [17]

\begin{tabular}{|c|c|c|c|}
\hline $\begin{array}{l}\text { Clinicopathological } \\
\text { characteristics }\end{array}$ & Patients, $\mathrm{n}$ & $\begin{array}{l}\text { NHERF1 } \\
\text { expression } \\
\text { (median) }\end{array}$ & $\mathrm{p}$ value \\
\hline \multicolumn{4}{|l|}{ Age, years } \\
\hline$\leq 55$ & 22 & 0.56 & \multirow[t]{2}{*}{ NS } \\
\hline$>55$ & 21 & 1.10 & \\
\hline \multicolumn{4}{|l|}{ Menopausal status } \\
\hline Pre & 15 & 0.59 & \multirow[t]{2}{*}{ NS } \\
\hline Post & 28 & 0.80 & \\
\hline \multicolumn{4}{|l|}{ Lymph node status } \\
\hline Negative & 23 & 0.51 & \multirow[t]{2}{*}{ NS } \\
\hline Positive & 20 & 0.80 & \\
\hline \multicolumn{4}{|l|}{ Tumor size, cm } \\
\hline$\leq 2$ & 10 & 0.87 & \multirow[t]{2}{*}{ NS } \\
\hline$>2$ & 22 & 0.58 & \\
\hline \multicolumn{4}{|l|}{ Histological grade } \\
\hline 1 & 6 & 0.41 & \multirow[t]{3}{*}{0.028} \\
\hline 2 & 16 & 0.66 & \\
\hline 3 & 17 & 3.14 & \\
\hline \multicolumn{4}{|c|}{ Hormonal receptor status } \\
\hline ER- & 18 & 0.79 & \multirow[t]{2}{*}{ NS } \\
\hline $\mathrm{ER}+$ & 18 & 0.95 & \\
\hline $\mathrm{PR}-$ & 17 & 0.51 & \multirow[t]{2}{*}{ NS } \\
\hline $\mathrm{PR}+$ & 24 & 1.15 & \\
\hline \multicolumn{4}{|l|}{ Proliferation index } \\
\hline MIB1- & 28 & 0.79 & \multirow[t]{2}{*}{ NS } \\
\hline MIB1+ & 15 & 0.62 & \\
\hline \multicolumn{4}{|c|}{ Nottingham Prognostic Index } \\
\hline Good & 7 & 0.41 & \multirow[t]{3}{*}{0.021} \\
\hline Moderate & 13 & 0.75 & \\
\hline Poor & 23 & 1.74 & \\
\hline
\end{tabular}

poxia $[22,23]$. The presence of NHERF1 in hypoxic tumors such as comedocarcinomas and the strong correlation with hypoxia inducible factor 1 alpha (HIF-1 $\alpha$ ), a marker of the hypoxic tumor microenvironment [24, 25], suggest that NHERF1 expression could be related to the tumor metabolic microenvironment which has been shown to play an important role in driving metastatic progression [26, 27].

Importantly, it was observed that NHERF1 protein expression is increased by hypoxia, and that this increase stimulates the activity of the $\mathrm{Na}^{+} / \mathrm{H}^{+}$exchanger 1 (NHE1), which results in a decrease in extracellular $\mathrm{pH}$ [6]. This provides, for the first time, a direct functional link between the hypoxic and acidic tumor microenvironments and their integration to drive increased tumor cell aggressiveness. Preliminary data from our laboratories show that analogous to HIF-1 $\alpha[24,25]$ this hypoxia-driven increase is due to an inhibition of the $26 \mathrm{~S}$ proteasome during hypoxia. Interestingly, NHERF1 binds to the epidermal growth factor receptor (EGFR) in an EGF-dependent manner to stabilize EGFR in the membrane and increase its downstream signaling, and, in this way, closes a positive-feedback loop that integrates local growth factor and hypoxic signals to further drive metastatic growth through the up-regulation of the NHE1 and subsequent acidification of the extracellular environment [26, 27].

$\mathrm{NS}=$ Not significant $\mathrm{ER}=$ estrogen receptor; $\mathrm{PR}=$ progesterone receptor. 
cantly increased with increasing tumor cytohistological grade and with a poorer prognosis as defined by Nottingham Prognostic Index (NPI) [30, 31]. This prognostic index, based on tumor size, tumor grade, and nodal status, is useful in predicting outcome in patients with operable breast cancer. Using the NPI index, it was observed that tissue NHERF1 protein expression was significantly higher in cytohistological undifferentiated tumors (G3) compared to differentiated tumors (G1-G2) and in tumors with a worse prognosis compared with those with a better prognosis. Interestingly, this association was also present when NHERF1 expression was evaluated by WB in peripheral blood lymphocytes of breast cancer patients; in fact, in a preliminary series of subjects, lymphocyte NHERF1 expression was significantly higher in patients with breast cancer with respect to that in healthy subjects. Indeed, a strong association between lymphocyte NHERF1 expression and ER expression in ER-positive tumors was also observed, in line with previous reports $[5,6,8]$. Altogether, these findings seem to underline a possible involvement of both the innate and the adaptive immune system in breast cancer etiology [32, 33].

\section{NHERF1 and HER2/neu: Interacting Partners}

As a scaffolding protein, NHERF1 recruits membrane and cytoplasmic proteins into functional complexes through its PDZ domains. NHERF1 is associated with a number of G proteincoupled receptors, ion channels, and growth factor TK receptors, such as the platelet-derived growth factor receptor [34] and the EGFR [35], which promote dimerization and activation of mitogenic signals $[34,36]$. These functions have been confirmed in the breast cancer model with demonstration of a critical role for these adaptor proteins in TK signal transduction [37] and growth regulation [17]. In particular, it is known that NHERF1 binds to the EGFR in normal and tumor cells to regulate cell trafficking and sensitivity to drugs $[4,35,38]$. Moreover, the interaction with HER2/neu has been deeply studied. In normal human breast cells, NHERF1 localized at the apical membrane of normal epithelial cells, and HER2/ neu maintained its physiological ability to respond to different signals. In HER2/neu-overexpressing DCIS, the receptor colocalized with NHERF1 at membrane level; conversely, in in- vasive tumors, synchronous metastatic lymph nodes, and metachronous distant metastases, NHERF1 becomes mostly cytoplasmic in cells of the tumor nests that are no longer polarized [19].

\section{Conclusions and Perspectives}

In conclusion, human NHERF1 is a scaffolding protein that recruits membrane receptors/transporters and cytoplasmic signaling proteins into functional complexes, important for the coordination of multiple signaling pathways such as those depending on TK receptors [4]. Its subcellular localization is altered in breast cancer with a predominant cytoplasmic expression. Its overexpression is associated with aggressive clinical parameters, unfavorable prognosis, and increased tumor hypoxia. Moreover, NHERF1 is overexpressed in circulating lymphocytes of breast cancer patients and associated with the same clinical parameters as the tumor. In addition, NHERF1 is strongly related to HER2/neu expression in invasive tumors and distant metastases. As a scaffolding protein, it is able to create new signaling pathways driving the subverted cellular functions exhibited by tumor cells; and as it binds to HER2/ neu, NHERF1 could potentially address 3 different clinical perspectives: i) be a new predictive marker for better a priori identification of patients/tumors that will respond to the treatment; ii) provide a way of increasing the sensitivity to trastuzumab in some non-responders, possibly by increasing its residence time in the plasma membrane and, therefore, its availability to trastuzumab; iii) be a novel target that could potentially be used in combined therapy with trastuzumab to increase its efficiency and/or transform non-responders into responders.

\section{Acknowledgement}

Partially supported by the Italian Ministry of Health, 'Programma Integrato Oncologia (PIO) 2007'.

\section{Conflict of Interest}

The authors declare that no competing interests exist.

\section{References}

1 Khatcheressian JL, Wolff AC, Smith TJ, Grunfeld E, Muss HB, Vogel VG, Halberg F, Somerfield MR, Davidson NE; American Society of Clinical Oncology: American Society of Clinical Oncology 2006 update of the breast cancer follow-up and management guidelines in the adjuvant setting. $\mathrm{J}$ Clin Oncol 2006;24:5091-5097.

2 Nourry C, Grant SG, Borg JP: PDZ domain proteins: plug and play! Sci STKE 2003;2003:RE7.
Brône B, Eggermont J: PDZ proteins retain and regulate membrane transporters in polarized epithelial cell membranes. Am J Physiol Cell Physiol 2005;288:C20-29

4 Weinman EJ, Hall RA, Friedman PA, Liu-Chen LY, Shenolikar S: The association of NHERF adaptor proteins with $\mathrm{g}$ protein-coupled receptors and receptor tyrosine kinases. Annu Rev Physiol 2006; 68:491-505.

\footnotetext{
5 Song J, Bai J, Yang W, Gabrielson EW, Chan DW, Zhang Z: Expression and clinicopathological significance of oestrogen-responsive ezrin-radixinmoesin-binding phosphoprotein 50 in breast cancer. Histopathology 2007;51:40-53.
} 
6 Cardone RA, Bellizzi A, Busco G, Weinman EJ, Dell'Aquila ME, Casavola V, Azzariti A, Mangia A, Paradiso A, Reshkin SJ: The NHERF1 PDZ2 domain regulates PKA-RhoA-p38-mediated NHE1 activation and invasion in breast tumor cells. Mol Biol Cell 2007;18:1768-1780.

7 Reczek D, Berryman M, Bretscher A: Identification of EBP50: a PDZ-containing phosphoprotein that associates with members of the ezrin-radixinmoesin family. J Cell Biol 1997;139:169-179.

$\checkmark 8$ Stemmer-Rachamimov AO, Wiederhold $\mathrm{T}$, Nielsen GP, James M, Pinney-Michalowski D, Roy JE, Cohen WA, Ramesh V, Louis DN: NHE-RF, a merlin-interacting protein, is primarily expressed in luminal epithelia, proliferative endometrium, and estrogen receptor-positive breast carcinomas. Am J Pathol 2001;158:57-62.

$\checkmark 9$ Fouassier L, Duan CY, Feranchak AP, Yun CH, Sutherland E, Simon F, Fitz JG, Doctor RB: Ezrinradixin-moesin-binding phosphoprotein 50 is expressed at the apical membrane of rat liver epithelia. Hepatology 2001;33:166-176.

10 Weinman EJ, Steplock D, Wang Y, Shenolikar S Characterization of a protein cofactor that mediates protein kinase $\mathrm{A}$ regulation of the renal brush border membrane $\mathrm{Na}(+)-\mathrm{H}+$ exchanger. J Clin Invest 1995;95:2143-2149.

-11 Dai JL, Wang L, Sahin AA, Broemeling LD Schutte M, Pan Y: NHERF $(\mathrm{Na}+\mathrm{H}+$ exchanger regulatory factor) gene mutations in human breast cancer. Oncogene 2004;23:8681-8687.

12 Plummer SJ, Adams L, Simmons JA, Casey G: Localization of a growth suppressor activity in MCF7 breast cancer cells to chromosome 17q24-q25. Oncogene 1997;14:2339-2345.

13 Orsetti B, Courjal F, Cuny M, Rodriguez C, Theillet C: $17 \mathrm{q} 21-\mathrm{q} 25$ aberrations in breast cancer: combined allelotyping and CGH analysis reveals 5 regions of allelic imbalance among which two correspond to DNA amplification. Oncogene 1999;18: 6262-6270.

14 Presneau N, Dewar K, Forgetta V, Provencher D, Mes-Masson AM, Tonin PN: Loss of heterozygosity and transcriptome analyses of a $1.2 \mathrm{Mb}$ candidate ovarian cancer tumor suppressor locus region at 17q25.1-q25.2. Mol Carcinog 2005;43:141-154.

15 Shibata T, Chuma M, Kokubu A, Sakamoto M, Hirohashi S: EBP50, a beta-catenin-associating protein, enhances Wnt signaling and is overexpressed in hepatocellular carcinoma. Hepatology 2003;38:178-186.
16 Fraenzer JT, Pan H, Minimo L Jr, Smith GM, Knauer D, Hung G: Overexpression of the NF2 gene inhibits schwannoma cell proliferation through promoting PDGFR degradation. Int $\mathrm{J}$ Oncol 2003;23:1493-1500.

17 Voltz JW, Weinman EJ, Shenolikar S: Expanding the role of NHERF, a PDZ-domain containing protein adapter, to growth regulation. Oncogene 2001;20:6309-6314

18 Schindelmann S, Windisch J, Grundmann R, Kreienberg R, Zeillinger R, Deissler H: Expression profiling of mammary carcinoma cell lines: correlation of in vitro invasiveness with expression of CD24. Tumor Biol 2002;23:139-145.

19 Mangia A, Chiriatti A, Bellizzi A, Malfettone A, Stea B, Zito FA, Reshkin SJ, Simone G, Paradiso A: Biological role of NHERF1 protein expression in breast cancer. Histopathology 2009;55:600-608.

20 Georgescu MM, Morales FC, Molina JR, Hayashi Y: Roles of NHERF1/EBP50 in cancer. Curr Mol Med 2008;8:459-468.

21 Moriya T, Silverberg SG: Intraductal carcinoma (ductal carcinoma in situ) of the breast. A comparison of pure noninvasive tumors with those including different proportions of infiltrating carcinoma. Cancer 1994;74:2972-2978.

22 Inouye T, Inokuchi M, Shimizu K, Abe K: Interstitial vascular reaction of naturally occurring mammary adenocarcinoma in old $\mathrm{C} 3 \mathrm{H} / \mathrm{HeJ}$ female mice. Jikken Dobutsu 1984;33:151-157.

23 Favaro E, Nardo G, Persano L, Masiero M, Moserle L, Zamarchi R, Rossi E, Esposito G, Plebani M, Sattler U, Mann T, Mueller-Klieser W, Ciminale V, Amadori A, Indraccolo S: Hypoxia inducible factor-1alpha inactivation unveils a link between tumor cell metabolism and hypoxia-induced cell death. Am J Pathol 2008;173:1186-1201.

24 Covello KL, Simon MC: HIFs, hypoxia, and vascular development. Curr Top Dev Biol 2004;62:37-54. 25 Zhong H, De Marzo AM, Laughner E, Lim M, Hilton DA, Zagzag D, Buechler P, Isaacs WB, Semenza GL, Simons JW: Overexpression of hypoxia-inducible factor 1alpha in common human cancers and their metastases. Cancer Res 1999;59: 5830-5835.

26 Gillies RJ, Raghunand N, Karczmar GS, Bhujwalla ZM: MRI of the tumor microenvironment. J Magn Reson Imaging 2002;16:430-450.

27 Cardone RA, Casavola V, Reshkin SJ: The role of disturbed $\mathrm{pH}$ dynamics and the $\mathrm{Na}+\mathrm{H}+$ exchanger in metastasis. Nat Rev Cancer 2005;5:786-795.
28 Ediger TR, Kraus WL, Weinman EJ, Katzenellenbogen BS: Estrogen receptor regulation of the $\mathrm{Na}+\mathrm{H}+$ exchange regulatory factor. Endocrinology 1999;140:2976-2982.

29 Harrington WR, Sheng S, Barnett DH, Petz LN, Katzenellenbogen JA, Katzenellenbogen BS Activities of estrogen receptor alpha- and betaselective ligands at diverse estrogen responsive gene sites mediating transactivation or transrepression. Mol Cell Endocrinol 2003;206:13-22.

30 Hermanek P, Sobin LH (eds): UICC TNM: Classification of Malignant Tumours, 4th ed. New York, John Wiley and Sons, 1988

31 Elston CW, Ellis IO: Pathological prognostic factors in breast cancer. I. The value of histological grade in breast cancer: experience from a large study with long-term follow-up. Histopathology 2002;41:154-161.

32 Bereznaya NM, Kirnasovskaya EA, Vinnichuk YD, Belova OB, Lukyanova NY: Expression of CD40 by the cells of benign and malignant breast tumors and antitumor action of autologous lymphocytes against chemoresistant and chemosensitive tumors. Exp Oncol 2008;30:295-299.

33 Standish LJ, Sweet ES, Novack J, Wenner CA Bridge C, Nelson A, Martzen M, Torkelson C: Breast cancer and the immune system. J Soc Integr Oncol 2008;6:158-168.

34 Maudsley S, Zamah AM, Rahman N, Blitzer JT, Luttrell LM, Lefkowitz RJ, Hall RA: Plateletderived growth factor receptor association with $\mathrm{Na}(+) / \mathrm{H}(+)$ exchanger regulatory factor potentiates receptor activity. Mol Cell Biol 2000;20:83528363.

35 Lazar CS, Cresson CM, Lauffenburger DA, Gill $\mathrm{GN}$ : The $\mathrm{Na}+\mathrm{H}+$ exchanger regulatory factor stabilizes epidermal growth factor receptors at the cell surface. Mol Biol Cell 2004;15:5470-5480.

36 Cao TT, Deacon HW, Reczek D, Bretscher A, von Zastrow M: A kinase-regulated PDZ-domain interaction controls endocytic sorting of the beta2adrenergic receptor. Nature 1999;401:286-290.

37 Weinman EJ, Steplock D, Wade JB, Shenolikar $S$ : Ezrin binding domain-deficient NHERF attenuates cAMP-mediated inhibition of $\mathrm{Na}(+) / \mathrm{H}(+)$ exchange in OK cells. Am J Physiol Renal Physiol 2001;281:F374-380.

38 Pan Y, Weinman EJ, Dai JL: Na+/H+ exchanger regulatory factor 1 inhibits platelet-derived growth factor signalling in breast cancer cells. Breast Cancer Res 2008;10:R5. 